\title{
Physicochemical and Microbiological Properties and Humic Substances of Composts Produced with Food Residues
}

\author{
Ana K. da C. Ferreira ${ }^{1}$, Nildo da S. Dias ${ }^{1}$, Francisco S. de Sousa Junior ${ }^{2}$, Daianni A. da C. Ferreira ${ }^{1}$, \\ Cleyton dos S. Fernandes ${ }^{1}$, Lizandra E. F. Lucas ${ }^{1}$, Kaline D. Travassos ${ }^{1}$ \& Francisco V. da S. Sá ${ }^{3}$ \\ ${ }^{1}$ Center of Agrarian Sciences, Federal Rural University of the Semi-Arid, Mossoró, RN, Brazil \\ ${ }^{2}$ Department of Exact, Technological and Human Sciences, Federal Rural University of the Semi-Arid, Angicos, \\ RN, Brazil \\ ${ }^{3}$ Academic Unit of Agricultural Engineering, Federal University of Campina Grande, Campina Grande, PB, \\ Brazil \\ Correspondence: Francisco V. da S. Sá, Academic Unit of Agricultural Engineering, Federal University of \\ Campina Grande, Paraíba, Brazil. Tel: 55-083-99861-9267. E-mail: vanies_agronomia@hotmail.com
}

Received: September 28, 2017

doi:10.5539/jas.v10n1p180

\author{
Accepted: November 7, 2017 Online Published: December 15, 2017 \\ URL: https://doi.org/10.5539/jas.v10n1p180
}

\begin{abstract}
The consolidation of a wide and effective management system of solid residues, especially biodegradable ones, is one of the great challenges of current society. Composting was evaluated as an option of organic fertilization for soil enrichment, using raw food residues in substitution to bovine manure. The compost piles were built with $30 \%$ of biodegradable residues mixed with $70 \%$ of ground tree pruning material. The effects of different proportions of food residues (FR) and bovine manure $(\mathrm{BM})$ as source of carbon were tested in 5 treatments $\left(\mathrm{T}_{1}=\right.$ $15 \% \mathrm{BM}+15 \% \mathrm{FR}, \mathrm{T}_{2}=20 \% \mathrm{BM}+10 \% \mathrm{FR}, \mathrm{T}_{3}=10 \% \mathrm{BM}+20 \% \mathrm{FR}, \mathrm{T}_{4}=30 \% \mathrm{BM}$ and $\mathrm{T}_{5}=$ control, $\left.30 \% \mathrm{FR}\right)$, in randomized blocks, under open field conditions for 90 days. The $\mathrm{pH}$, temperature and moisture content of the compost were measured weekly. The aged compost was evaluated for physicochemical and microbiological properties and carbon contents in the humic substances. The analyses of the results indicated that all studied composts reached the maturation stage with satisfactory contents of humic substances, macronutrients, and micronutrients, indicating that food residues can be used as a source of carbon in compost piles to produce organic fertilizers. The contents of the evaluated chemical contaminants were much lower than those established in the main legislation and current normative instructions and, in terms of contamination by pathogens, there was the absence of total coliforms, thermo tolerant coliforms, and Salmonellas.
\end{abstract}

Keywords: nutrients recycling, organic fertilization, $\mathrm{C} / \mathrm{N}$ ratio

\section{Introduction}

A number of solid residues disposed of by the population is extremely large and, when inadequately disposed, they become a problem for society, because they can cause environmental impacts, modifying the quality of soil, air and water bodies, which represents a risk to the public health (Bulcão et al., 2010).

Thus, to face the situation in the social context of the country, there arise individual (garbage collectors) and collective (associated groups, cooperatives, and companies) initiatives whose operations are based on the process of collection, separation, reuse and/or recycling of these materials.

Currently, there are two recycling associations in the city of Mossoró/RN: Associação Comunitária Reciclando para a Vida (ACREVI) and Associação dos Catadores de Material Reciclável de Mossoró (ASCAMAREM) (Cavalcanti et al., 2011). These associations work with the selective collection and collaborate to minimize the negative impacts that the residues can cause to the environment (Ferreira et al., 2012).

However, as in most recycling associations in Brazil, there are no programs for the recycling of biodegradable materials and their disposal in landfills is common, causing serious environmental problems. From the sustainability point of view, biodegradable residue must efficiently return to the economic and productive cycle, to guarantee their final disposal. 
In this context, composting becomes an option for the reuse of biodegradable residues as one form of production of organic fertilization, which can be used to enrich soil, since it provides nutrients that are essential to its fertility, besides meeting sanitary, social, ecological and economic aspects (Inácio \& Miller, 2009).

Nevertheless, to avoid negative environmental impacts of the use of the composting of biodegradable residues in agriculture, it is necessary to define parameters relative to physicochemical and microbiological quality, besides the possible contamination by pathogens or heavy metals. Thus, composting was evaluated as an option for an organic source of fertilization in agriculture using raw material food residue in substitution to bovine manure.

\section{Material and Methods}

The experiment was carried out in the courtyard of the Associação Comunitária Reciclando para a Vida (ACREVI), located in the Nova Vida neighborhood, municipality of Mossoró - RN (5 $5^{\circ} 14^{\prime} 9^{\prime \prime}$ S; $37^{\circ} 18^{\prime} 59^{\prime \prime}$ W; 18 $\mathrm{m}$ asl.).

The biodegradable residues (bovine manure and food residues) used for the composts were collected in popular restaurants and households of the local urban area. Filling materials consisted of tree pruning residue collected by the urban cleaning service of the municipality. In total, approximately 7 tons of vegetal material, $1,500 \mathrm{~kg}$ of bovine manure and $1,500 \mathrm{~kg}$ of food residue were collected. All piles were built with $70 \%$ of the vegetal material (V) and 30\% of bovine manure (BM) and food residues (FR), as recommended by Pereira Neto (2007).

The effects of different proportions of food residues (FR) and bovine manure (BM) as source of carbon were tested in 5 treatments $\left(\mathrm{T}_{1}=15 \% \mathrm{BM}+15 \% \mathrm{FR}, \mathrm{T}_{2}=20 \% \mathrm{BM}+10 \% \mathrm{FR}, \mathrm{T}_{3}=10 \% \mathrm{BM}+20 \% \mathrm{FR}, \mathrm{T}_{4}=30 \% \mathrm{BM}\right.$ and $\mathrm{T}_{5}=30 \% \mathrm{FR}$ ), in randomized blocks, under open field conditions during 90 days.

The compost piles were built with a conical shape, $1.60 \mathrm{~m}$ high and $2.00 \mathrm{~m}$ wide, spaced and parallel to one another to facilitate the turning, passage of materials and access. The manual turning of the compost piles occurred every three days in the first week of composting and, subsequently, every ten days. The piles were daily irrigated using tap water.

During the maturation process, the piles were weekly monitored through measurements of the parameters temperature, moisture, and $\mathrm{pH}$. In addition, the contents of total organic carbon (TOC), total nitrogen (TN) and $\mathrm{C} / \mathrm{N}$ ratio were determined in four periods, 2 during the degradation stage of the composts (beginning and at 10 days from the building of the piles) and the others at 30 and 60 days after the beginning of the composting and during maturation.

TOC was determined through the wet oxidation method with external heating, while TN was determined through the wet digestion method in the open system, using a block digester (Tedesco et al., 1995; Santos et al., 2009). The $\mathrm{C} / \mathrm{N}$ ratio was obtained by the ratio between the TOC and nitrogen, expressed in percentage.

After maturation, the composts were analyzed for humic substances (Swift, 2001), macro and micronutrients, heavy metals (Santos et al., 2009), total coliforms, thermo tolerant coliforms and Salmonella (Siqueira, 1995). For the determination of humic substances, the samples of each treatment were ground, passed through a 60 -mesh sieve $(0.210 \mathrm{~mm})$ and subjected to the fractioning of humic substances (swift, 2001). From this fractioning, the fractions corresponding to fulvic acids, humic acids, and humins were obtained through the differential solubility in acidic and alkaline solutions.

The contents of macro- and micronutrients and chemical contaminants were determined through wet digestion in a closed system using a microwave oven as a source of heat and concentrated nitric acid to digest the compost. Then, the liquid extract obtained from this process was analyzed for the contents of $\mathrm{Cu}, \mathrm{Zn}, \mathrm{Fe}, \mathrm{Mn}, \mathrm{Cd}, \mathrm{Ni}, \mathrm{Pb}$, $\mathrm{Ca}$ and $\mathrm{Mg}$, through atomic absorption spectrophotometry, and $\mathrm{P}, \mathrm{Na}$ and $\mathrm{K}$, through calorimetry and flame spectrophotometry, respectively (Santos et al., 2009).

Total coliforms and thermo tolerant coliforms were evaluated using the most probable number (MPN) technique, also known as a multiple-tube method (Siqueira, 1995).

All analyses were performed in triplicate. The results were subjected to analysis of variance $(p<0,05)$, using the statistical program ASSISTAT 7.7 (Silva \& Azevedo, 2016). Tukey test was used to compare the mean values.

\section{Results and Discussion}

\subsection{Composition and Characteristics of the Compost piles}

Table 1 shows the composition and characteristics of the piles during the composting process. At the end of the composting, the results showed that there is no variation of temperature $\left(35^{\circ} \mathrm{C}\right)$ between the studied treatments and the observed values allow the reduction and/or elimination of pathogens. However, there were small 
variations of $\mathrm{pH}(7.3$ to 7.8$)$, TOC (7 to $11 \%)$ and $\mathrm{TN}(0.5$ to $0.8 \%)$. Regarding the $\mathrm{C} / \mathrm{N}$ ratio, the piles of the treatments with $30 \%$ of food residues $\left(\mathrm{OC}_{5}\right)$ showed higher $\mathrm{C} / \mathrm{N}$ ratio than the other treatments, while the $\mathrm{OC}_{4}$ compost pile showed the lowest moisture content (48\%).

Table 1. Composition and parameters presented in the piles during the composting process

\begin{tabular}{|c|c|c|c|c|c|c|c|}
\hline Piles & $\mathrm{C} \%$ & $\mathrm{~T}^{\circ} \mathrm{C}$ & U\% & $\mathrm{pH}$ & TOC $\%$ & TN\% & $\mathrm{C} / \mathrm{N} \%$ \\
\hline \multirow{3}{*}{$\mathrm{OC}_{1}$} & $70 \mathrm{VM}$ & St. $\approx 35$ & St. 55 & St. $\approx 6.0$ & St. $\approx 23$ & St. 0.9 & St. $\approx 26$ \\
\hline & $15 \mathrm{BM}$ & Int. $\approx 55$ & Int. 45 & Int. 7.1-7.2 & Int. $\approx 12$ & Int. 0.8 & Int. $\approx 15$ \\
\hline & $15 \mathrm{FR}$ & En. $\approx 35$ & En. 51 & St. 7.8 & En. $\approx 11$ & En. 0.8 & En. $\approx 13$ \\
\hline \multirow{3}{*}{$\mathrm{OC}_{2}$} & $70 \mathrm{VM}$ & St. $\approx 35$ & St. 55 & St. 6.0 & St. $\approx 19$ & St. 0.8 & St. $\approx 23$ \\
\hline & $20 \mathrm{BM}$ & Int. $\approx 55$ & Int. 45 & St. 6.9-7.2 & Int. $\approx 10$ & Int. 0.7 & Int. $\approx 14$ \\
\hline & $10 \mathrm{FR}$ & En. $\approx 35$ & En. 51 & En. 7.3 & En. $\approx 9$ & En. 0.7 & En. $\approx 13$ \\
\hline \multirow{3}{*}{$\mathrm{OC}_{3}$} & $70 \mathrm{VM}$ & St. $\approx 35$ & St. $\approx 40$ & St. 6.4 & St. $\approx 19$ & St. 0.7 & St. $\approx 25$ \\
\hline & $10 \mathrm{BM}$ & Int. $\approx 55$ & Int. $28-40$ & Int. 5.8-6.9 & Int. $\approx 9$ & Int. 0.5 & Int. $\approx 19$ \\
\hline & $20 \mathrm{FR}$ & En. $\approx 35$ & En. 51 & En. 7.6 & En. $\approx 7$ & En. 0.5 & En. $\approx 14$ \\
\hline \multirow{3}{*}{$\mathrm{OC}_{4}$} & $70 \mathrm{VM}$ & St. $\approx 35$ & St. $\approx 20$ & St. 6.8 & St. $\approx 17$ & St. 0.9 & St. $\approx 19$ \\
\hline & $30 \mathrm{BM}$ & Int. $\approx 55$ & Int. 32-35 & Int. $6.8-7.2$ & Int. $\approx 11$ & Int. 0.7 & Int. $\approx 15$ \\
\hline & $0 \mathrm{FR}$ & En. $\approx 35$ & En. 48 & En. 7.8 & En. $\approx 10$ & En. 0.7 & En. $\approx 14$ \\
\hline \multirow{3}{*}{$\mathrm{OC}_{5}$} & $70 \mathrm{VM}$ & St. $\approx 35$ & St. $\approx 61$ & St. 5.5 & St. $\approx 17$ & St. 0.7 & St. $\approx 24$ \\
\hline & $0 \mathrm{BM}$ & Int. $\approx 55$ & Int. 55-62 & Int. 5.8-6.0 & Int. $\approx 10$ & Int. 0.6 & Int. $\approx 17$ \\
\hline & $30 \mathrm{FR}$ & En. $\approx 35$ & En. 53 & En. 7.5 & En. $\approx 9,5$ & En. 0.6 & En. $\approx 16$ \\
\hline
\end{tabular}

Note. $\mathrm{C}=$ composition; $\mathrm{T}=$ temperature; $\mathrm{U}=$ moisture; $\mathrm{VM}=$ vegetal material; $\mathrm{TOC}=$ total organic carbon; $\mathrm{TN}$ $=$ total nitrogen; $\mathrm{C} / \mathrm{N}=$ nitrogen carbon ratio; $\mathrm{BM}=$ bovine manure; $\mathrm{FR}=$ food residues; St. = start; Int. = intermediary; En. = end.

\subsection{Carbon Contents in Humic Substances}

According to the ANOVA, the variable carbon fractions of the humic acids (C-HA), fulvic acids (C-FA) and humin $(\mathrm{C}-\mathrm{HUM})$ were significantly influenced $(\mathrm{p}<0.01)$ by the proportions of food leftovers of the compost piles (Table 2).

Table 2. Analysis of variance of carbon fraction contents of the humic substances in organic composts produced with different proportions of bovine manure and food residues

\begin{tabular}{lllll}
\hline \multirow{2}{*}{ Variation sources } & \multirow{2}{*}{ Freedom degree } & \multicolumn{3}{c}{ Carbon fractions } \\
\cline { 3 - 5 } & & $\mathrm{C}-\mathrm{AH}$ & $\mathrm{C}-\mathrm{AF}$ & $\mathrm{C}-\mathrm{HUM}$ \\
\hline Treatments & 4 & $0.22^{* *}$ & $3.61^{* *}$ & $1341.18^{* *}$ \\
Error & 10 & 0 & 0 & 0.08 \\
Total & 14 & 0.91 & 14.45 & 5365.49 \\
CV $(\%)$ & & 1.86 & 1.82 & 0.19 \\
\hline
\end{tabular}

Note. ns; *; ** not significant, significant at the 0.05 and 0.01 level of significance according to the $\mathrm{F}$ test; $\mathrm{CV}=$ coefficient of variation.

In general, among the fractions of humic substances, there was higher $\mathrm{C}$ content in humins (C-HUM), followed by humic acid (C-HA) and fulvic acid (C-FA) (Figure 1). This high $\mathrm{C}$ content in C-HUM is possibly due to the lower solubility of this fraction associated with the high polymerization and, consequently, higher degree of stabilization. 

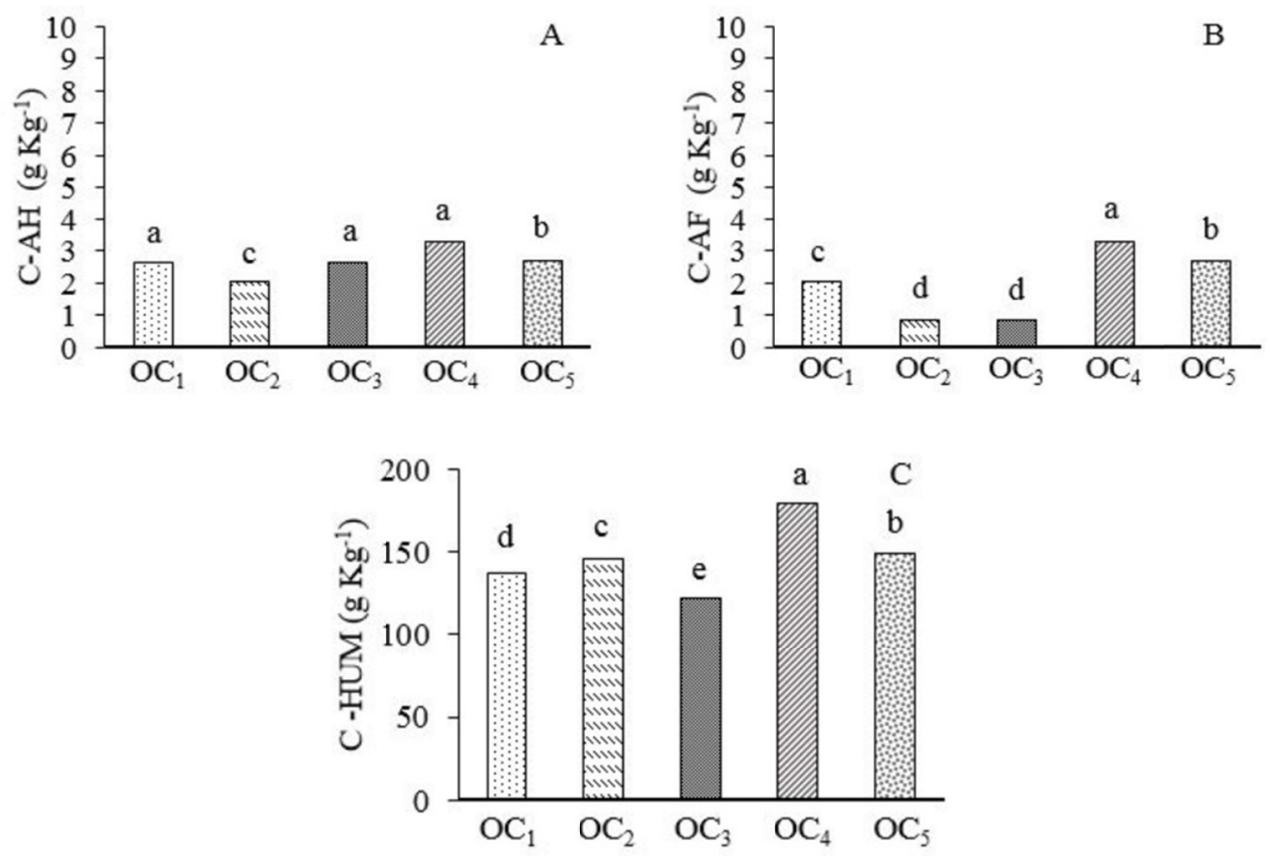

Figure 1. Mean values of the fractions C-HA (A), C-AF (B) and C-HUM (C) in organic composts produced with different proportions of bovine manure and food residues

Note. Averages followed by the same letter do not differ statistically by Tukey test at the $5 \%$ probability level.

The mean values of the fractions C-HUM, C-HA and C-FA stood out in the control pile (30\% BM) (Figure 1), which allows to infer that the decrease of diversity can cause increment in the mineralization rates, increasing the interaction of these fractions with the mineral portion present in the organic compost. It was observed that the means of the C-HA fractions did not differ statistically $(\mathrm{p}<0.05)$ in the piles $\mathrm{OC}_{1}(15 \% \mathrm{BM}$ and $15 \% \mathrm{FR})$ and $\mathrm{OC}_{3}(10 \% \mathrm{BM}$ and $20 \% \mathrm{FR})$, in relation to the control, which were more satisfactory in the evaluation of this fraction. However, these piles differed from $\mathrm{OC}_{2}(20 \% \mathrm{BM}$ and $10 \% \mathrm{FR})$ and $\mathrm{OC}_{5}(30 \% \mathrm{FR})$, which were considered as the worst in the estimate of C-HA.

Although $\mathrm{OC}_{1}$ and $\mathrm{OC}_{3}$ are similar to the control and considered as the most significant piles in the C-HA fraction evaluation, the control $\left(\mathrm{OC}_{4}\right)$ is even more expressive in the analysis of this fraction. Thus, when C-HA was evaluated in the other piles, it suffered a more relevant decrease in $\mathrm{OC}_{2}(38.3 \%)$, compared with the control. In the other piles, this reduction varied from 18 to $20 \%$ approximately, compared with $\mathrm{OC}_{4}$.

According to the means of C-FA, there was statistical difference between almost all piles in the final process. This demonstrated that the FA fraction is more sensitive to changes than HA. However, the pile $\mathrm{OC}_{4}$ was superior to the others regarding the quantification of C-HA, while $\mathrm{OC}_{2}$ and $\mathrm{OC}_{3}$ did not exhibit statistical differences, being considered as the worst in the estimate of this fraction.

In the quantification of the humin fraction, all piles were different ( $p>0.05)$, with the control $(30 \% \mathrm{BM})$ as the most significant and $\mathrm{OC}_{3}(10 \% \mathrm{BM}$ and $20 \% \mathrm{FR})$ as the least significant. This statistical difference in the piles can be a consequence of the microbial decomposition, which is particular, in its time, for each composting process (Matiz et al., 2015).

Silva et al. (2009) point out that there are studies in the literature relating the maturation degree of a compost to the characteristics of the humic compodst present, associating this parameter to the polymerization degree. Thus, it can be inferred that the produced composts were mature, since the final values of this C-HA/C-FA ratio were $1.63,2.33,3.00,1.25$, and 1.54 , for the samples collected in the final stage in the compost piles $\mathrm{OC}_{1}, \mathrm{OC}_{2}, \mathrm{OC}_{3}$, $\mathrm{OC}_{4}$, and $\mathrm{OC}_{5}$, respectively.

\subsection{Contents of Macro and Micronutrients of the Composts}

According to the ANOVA, there was a significant effect of the proportions of food residues in the compost on the variables nitrogen, phosphorus, potassium, calcium, copper, iron and zinc $(p<0.01)$, besides magnesium and manganese $(\mathrm{p}<0.05)$ (Table 3). 
Table 3. Analysis of variance of the nutrients in organic composts produced with different proportions of bovine manure and food residues

\begin{tabular}{lllllllllll}
\hline \multirow{2}{*}{ FV } & \multirow{2}{*}{$\mathrm{GL}$} & \multicolumn{8}{c}{ Nutrients } \\
\cline { 3 - 10 } & & $\mathrm{N}$ & $\mathrm{P}$ & $\mathrm{K}$ & $\mathrm{Ca}$ & $\mathrm{Mg}$ & $\mathrm{Cu}$ & $\mathrm{Mn}$ & $\mathrm{Fe}$ & $\mathrm{Zn}$ \\
\hline Treatments & 4 & $4.51^{* *}$ & $0.10^{* *}$ & $0.13^{* *}$ & $11.02^{* *}$ & $0.09^{*}$ & $36.60^{* *}$ & $1499.65^{*}$ & $1,031,226.33^{* * *}$ & $214.00^{* *}$ \\
Error & 10 & 0.02 & 0.00 & 0.00 & 0.77 & 0.02 & 3.22 & 267.03 & $139,875.65$ & 10.46 \\
Total & 14 & 18.18 & 0.39 & 0.61 & 51.78 & 0.52 & 178.63 & 8668.94 & $5,523,661.83$ & 960.58 \\
\hdashline $\mathrm{CV}(\%)$ & & 1.9 & 6.03 & 12.41 & 15.44 & 11.07 & 36.01 & 27.29 & 21.6 & 10.24 \\
\hline
\end{tabular}

Note. *; ** significant at the 0.05 and 0.01 level of significance according to the $\mathrm{F}$ test; $\mathrm{CV}=$ coefficient of variation

There was greater concentration of $\mathrm{N}$ and $\mathrm{Ca}$ in all organic composts, compared with the other analyzed macronutrients (Figure 2). In general, $\mathrm{N}$ stood out as the primary macronutrient in largest amount, since it showed the highest means in $\mathrm{OC}_{1}, \mathrm{OC}_{2}$ and $\mathrm{OC}_{4}$. The addition of the inoculant bovine manure, on the piles (Table 1) that formed these organic composts, may have been a factor that favored the increase in the concentration of this nutrient.
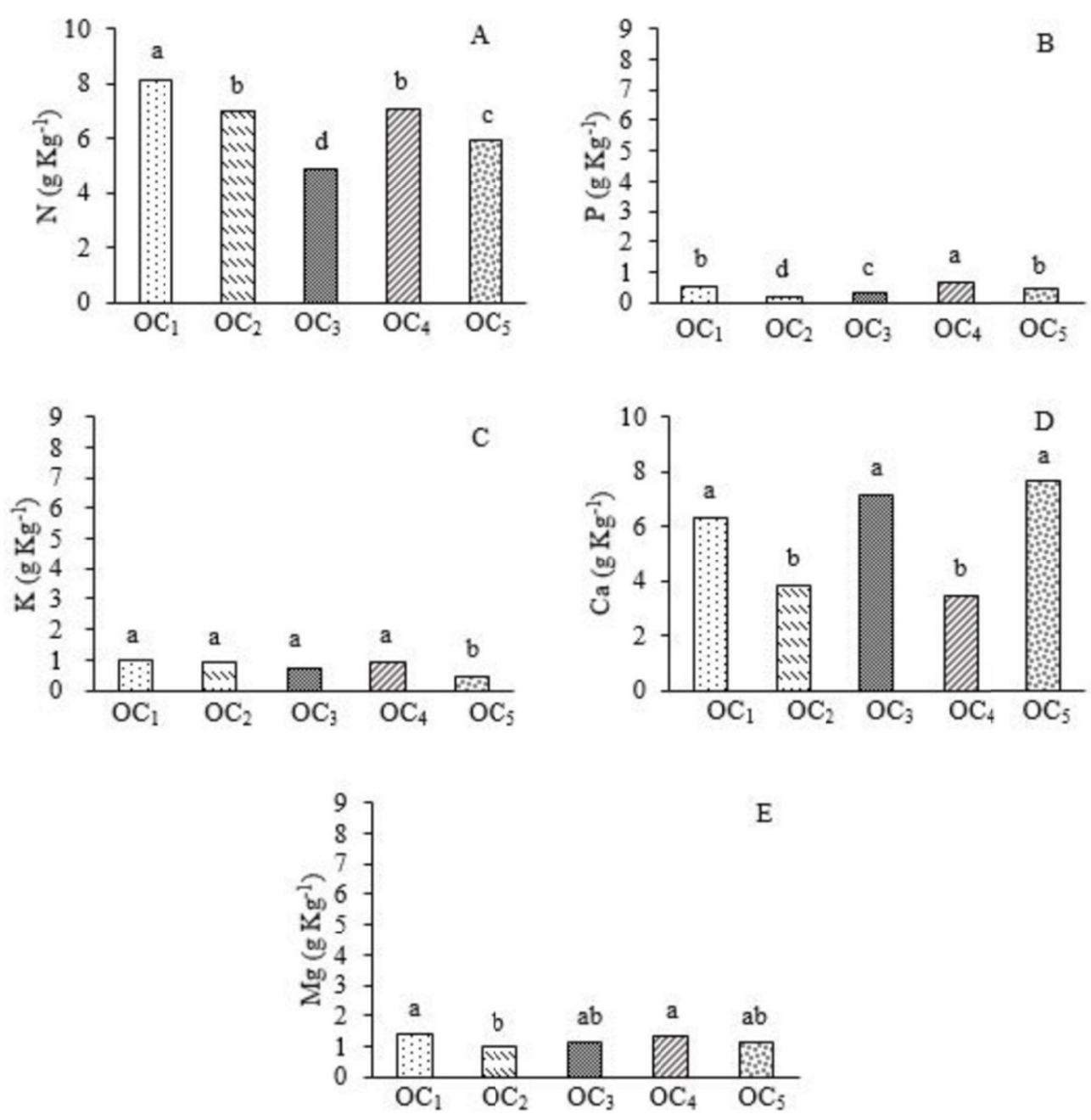

Figure 2. Mean values of macronutrients Nitrogen (A), Phosphorus (B), Potassium (C), Calcium (D) and Magnesium (E) in organic composts produced with different proportions of bovine manure and food residues Note. Averages followed by the same letter do not differ statistically by Tukey test at the $5 \%$ probability level. 
The other composts, $\mathrm{OC}_{3}$ and $\mathrm{OC}_{5}$, showed higher percentage of $\mathrm{Ca}$, possibly due to the increment of food leftovers in the composition of the piles (Table 1), which favor the formation of these composts.

Assessing wastewater biosolids composting, Matiz et al. (2015) verified that in regarding the physicochemical and nutritional characteristics, none of the treatments showed significant differences and their characteristics were similar and their values within norm.

As to the evaluated cationic micronutrients, $\mathrm{Fe}$ stood out over the others, exhibiting a higher concentration in all organic composts (OC), equivalent to 94.0, 96.6, 92.4, 94.5, and 94.5\% in $\mathrm{OC}_{1}, \mathrm{OC}_{2}, \mathrm{OC}_{3}, \mathrm{OC}_{4}$, and $\mathrm{OC}_{5}$, respectively. These values may have been due to the site where the experiment was installed, because the piles were built in an association of recyclable material collectors, where the piles are accommodated on the floor in contact with residues in the soil. Similar results were found by Primo et al. (2010), who analyzed the nutritional quality of organic compost produced with tobacco residues and observed high $\mathrm{Fe}$ concentrations.

In general, $\mathrm{OC}_{3}$ stood out as the most significant in the evaluation of $\mathrm{Cu}, \mathrm{Mn}$ and $\mathrm{Fe}$ (Figure 3). However, $\mathrm{OC}_{3}$ was not as relevant in the quantification of $\mathrm{Fe}$ as it was for $\mathrm{Cu}$ and $\mathrm{Mn}$. The $\mathrm{OC}_{5}$ was considered as the worst in the estimate of the analyzed micronutrients.

Regarding $\mathrm{Cu}$, the organic composts that stood out in the evaluation of this micronutrient were $\mathrm{OC}_{1}$ and $\mathrm{OC}_{3}$, while $\mathrm{OC}_{2}$ was statistically equal to $\mathrm{OC}_{4}$ and $\mathrm{OC}_{5}$. Despite that, $\mathrm{OC}_{3}$ was the most expressive in the evaluation of $\mathrm{Cu}$, because when it was analyzed in the other composts, there were reductions of $38.9 \%$ in $\mathrm{OC}_{1}, 65.6 \%$ in $\mathrm{OC}_{2}$, $70.4 \%$ in $\mathrm{OC}_{4}$ and $85.4 \%$ in $\mathrm{OC}_{5}$ (Figure 3 ).
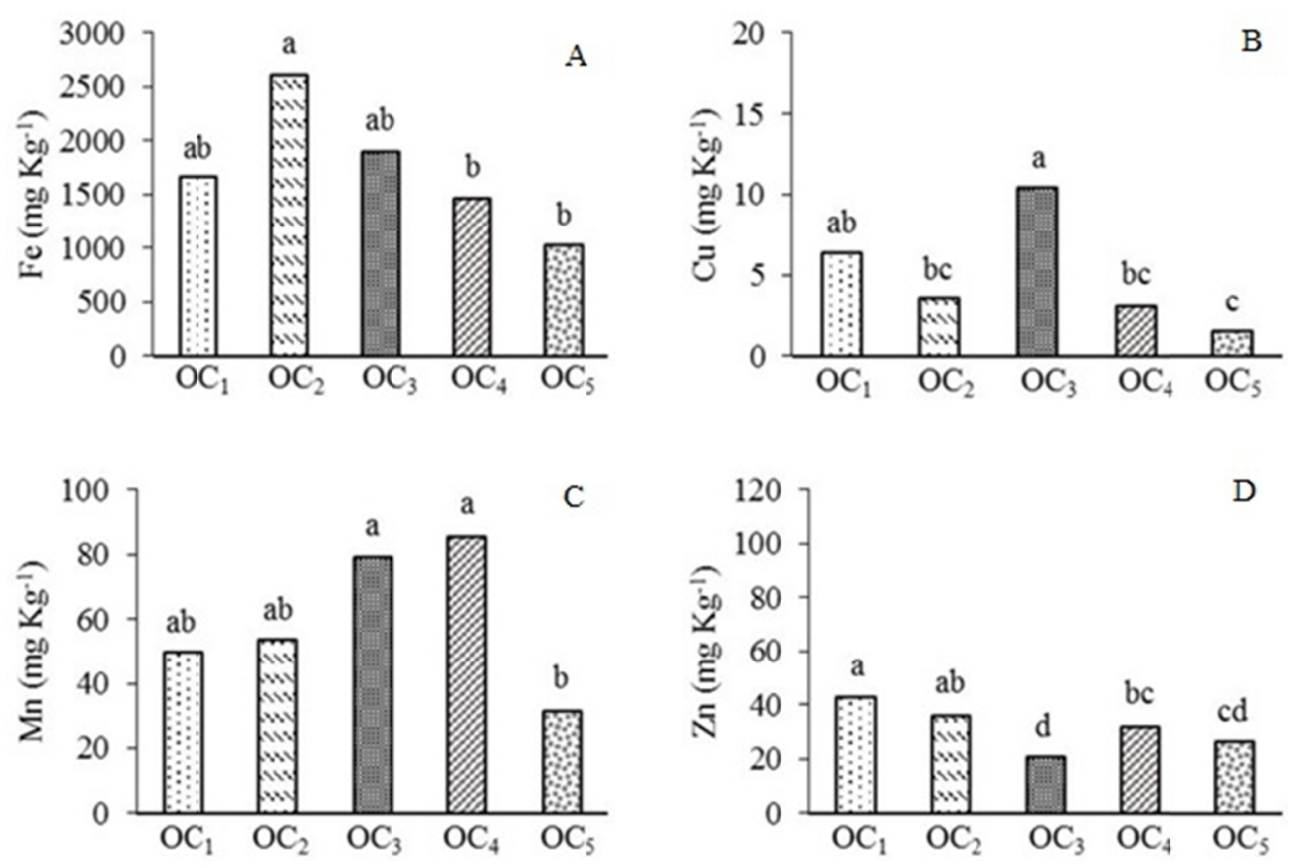

Figure 3. Mean values of micronutrients Iron (A), Copper (B), Manganese (C) and Zinc (D) in organic composts produced with different proportions of bovine manure and food residues

Note. Averages followed by the same letter do not differ statistically by Tukey test at the $5 \%$ probability level.

For the micronutrient $\mathrm{Mn}$, more relevant values were observed in the composts $\mathrm{OC}_{3}$ and $\mathrm{OC}_{4}$, while $\mathrm{OC}_{1}$ and $\mathrm{OC}_{2}$ were statistically equal and $\mathrm{OC}_{5}$ was the least prominent in the $\mathrm{Mn}$ analysis. It should be pointed out that, when $\mathrm{Mn}$ was evaluated in the $\mathrm{OCs}$ with statistically lower contents, $\mathrm{OC}_{4}$ showed reductions of approximately 42,38 and $64 \%$ in comparison to $\mathrm{OC}_{1}, \mathrm{OC}_{2}$, and $\mathrm{OC}_{5}$, respectively.

In the quantification of the nutrient $\mathrm{Zn}$, higher contents were observed in $\mathrm{OC}_{1}$, but it did not differ statistically from $\mathrm{OC}_{2} . \mathrm{OC}_{3}$ was the organic compost with lowest contents of $\mathrm{Zn}$, but it was statistically similar to $\mathrm{OC}_{5}$, which did not differ from $\mathrm{OC}_{4}$. It is ratified that $\mathrm{Zn}$ suffered a decrease in $\mathrm{OC}_{3}$, compared with the other analyzed 
composts. These reductions were approximately of $85,48,74$, and $63 \%$ referring to $\mathrm{OC}_{2}, \mathrm{OC}_{3}, \mathrm{OC}_{4}$, and $\mathrm{OC}_{5}$, respectively.

In general, the organic composts $\mathrm{OC}_{1}$ and $\mathrm{OC}_{4}$ stood out in the quantification of the macronutrients and $\mathrm{OC}_{3}$ in the evaluation of micronutrients. However, despite these differences in the quantification of nutrients in the different organic composts, it should be pointed out that there are no specifications of standard limits for the contents of nutrients analyzed in organic composts, because both macro and micronutrients are related to the type of matter used in the production of the compost or in the composition of the compost piles. Since these contents do not exist, studies conducted in this research line are adopted as reference, as well as concentrations considered as ideal for agriculture.

The values obtained in the present study indicate that the analyzed organic composts had good quality, since, according to Malavolta (1980), they have macro and micronutrients in adequate concentrations for agriculture.

\subsection{Heavy Metals}

According to the summary of the ANOVA, only nickel $(\mathrm{Ni})$ showed significant effect $(\mathrm{p}<0.01)$ of the proportions of food residues in the composting (Table 4).

Table 4. Analysis of variance of chemical contaminants in organic composts produced with different proportions of bovine manure and food residues

\begin{tabular}{lllll}
\hline \multirow{2}{*}{ FV } & \multirow{2}{*}{ GL } & \multicolumn{3}{c}{ Chemical contaminants } \\
\cline { 3 - 5 } & & $\mathrm{Ni}$ & $\mathrm{Cd}$ & $\mathrm{Pb}$ \\
\hline Treataments & 4 & $8.64^{* *}$ & $0.01^{\text {ns }}$ & $24.05^{\text {ns }}$ \\
Error & 10 & 0.04 & 0.02 & 7.31 \\
Total & 14 & 34.96 & 0.26 & 169.31 \\
CV $(\%)$ & & 5.51 & 52.79 & 76.9
\end{tabular}

Note. $\mathrm{ns}$; ** not significant and 0.01 level of significance according to the $\mathrm{F}$ test; $\mathrm{CV}=$ coefficient of variation.

As in the quantification of nutrients, there is not a specific legislation containing the acceptable concentrations of the metals that are considered as chemical contaminants to soil and/or plant; instead, there are proposals of resolution referring to the quality parameters for the organic compost (CONAMA resolution proposal 02/2016). This proposal presents the quality contents that the organic compost must have for any allowed application as fertilizers and soil conditioners, including agricultural, gardening and landscaping applications.

Thus, the values referenced in the present research were based on the proposals of resolution, studies and acceptable contents established by some countries of Europe and the United States (Table 5).

Table 5. Acceptable contents of chemical contaminants in $\mathrm{mg} \mathrm{kg}^{-1}$ for organic compost and the values found in the research

\begin{tabular}{llll}
\hline \multirow{2}{*}{ Countries/Resolutions } & \multicolumn{2}{c}{ Contaminants $\left(\mathrm{mg} \mathrm{K}^{-1}\right)$} \\
\cline { 2 - 4 } & $\mathrm{Ni}$ & $\mathrm{Cd}$ & $\mathrm{Pb}$ \\
\hline Germany & 50 & 15 & 150 \\
Austria & 200 & 6 & 900 \\
Switzerland & - & 3 & 150 \\
Italy & 200 & 10 & 500 \\
Netherlands & 50 & 2 & 20 \\
EUA & 100 & 10 & 500 \\
CONAMA Prop. Res $02 / 2016$ & 70 & 1,5 & 150 \\
$\mathrm{OC}_{1}$ & 0.8 & 0.2 & 1 \\
$\mathrm{OC}_{2}$ & 4.4 & 0.3 & 5.3 \\
$\mathrm{OC}_{3}$ & 4.2 & 0.3 & 4.3 \\
$\mathrm{OC}_{4}$ & 4.1 & 0.3 & 0.5 \\
$\mathrm{OC}_{5}$ & 5.1 & 0.3 & 3.6 \\
\hline
\end{tabular}

Note. $\mathrm{OC}_{1}(15 \% \mathrm{FR}+15 \% \mathrm{BM}) ; \mathrm{OC}_{2}(10 \% \mathrm{FR}+20 \% \mathrm{BM}), \mathrm{OC}_{3}(20 \% \mathrm{FR}+10 \% \mathrm{BM}), \mathrm{OC}_{4}(30 \% \mathrm{BM})$ and $\mathrm{OC}_{5}$ (30\%FR). 
Based on the adequate values of chemical contaminants presented in Table 5, all analyzed OCs contained adequate concentrations of the metals $\mathrm{Ni}, \mathrm{Cd}$ and $\mathrm{Pb}$, because the observed values were much lower than those established by the mentioned references.

Due to loss of carbon during composting process, the concentration of heavy metals may increase thus, its monitoring is essential (Matiz et al., 2015). According to Manios and Stentiford (2006), and Cai et al. (2007) the results obtained at end of the process can be higher for compared with raw material possibly due to volatilization of the materials, transformation of organic matter into $\mathrm{CO}_{2}$ and $\mathrm{NH}_{4}$ material weight loss.

The significant effect of the contaminant $\mathrm{Ni}$ when subjected to the test of means demonstrated that $\mathrm{OC}_{5}$ showed higher contents of this heavy metal, while $\mathrm{OC}_{2}, \mathrm{OC}_{3}$, and $\mathrm{OC}_{4}$ were statistically similar, and $\mathrm{OC}_{1}$ was the least prominent in the evaluation of this metal (Figure 4).

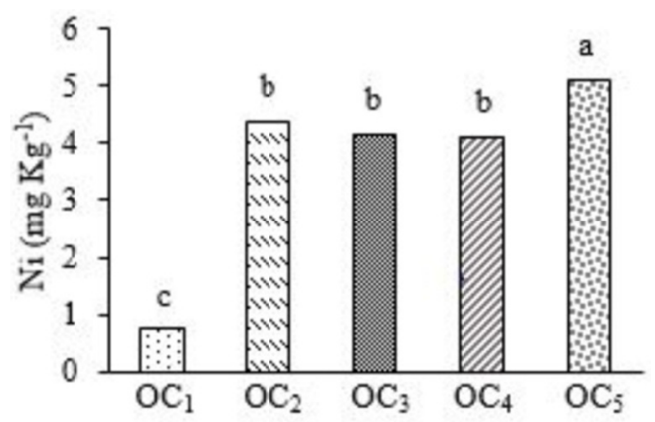

Figure 4. Mean values of contaminant Nickel in organic composts produced with different proportions of bovine manure and food residues

Note. Averages followed by the same letter do not differ statistically by Tukey test at the 5\% probability level.

Although $\mathrm{OC}_{5}$ is the most expressive in the analysis of $\mathrm{Ni}$, the concentration found in this compost is still considered much lower than those observed in the literature. Nickel is a heavy metal that, at high concentrations, can cause serious physiological disorders or even the death of the plants. At low concentrations, however, it is considered as an essential nutrient to plants, participating in metabolic processes as activator of urease (Berton et al., 2006; Pires \& Andrade, 2006; Wood et al., 2006).

\subsection{Microbiological Quality of the Composts}

The microbiological quality of the composts, the standards and criteria to confer their quality in relation to the analysis of Salmonella and coliforms, was evaluated following the Normative Instruction (NI) $n^{\circ} 27 / 2006$ of the Secretariat of Agriculture and Livestock Defense - SDA, for fertilizers, correctives, inoculants and biofertilizers, as well as the resolution proposal 02/2016 (CONAMA process 02000.001228/2015-37). These references indicate maximum allowed concentrations of pathogenic agents for humans, animals and plants.

In this context, there was no contamination by Salmonella species in the produced organic composts. In addition, the numbers of total coliforms in all produced composts were lower than the maximum value allowed, compared with organic fertilizers. The decontamination may have been a consequence of the maintenance of temperature for adequate time during the composting process, because, according to Orrico Júnior et al. (2009) and Liang et al. (2003), for the composting process to have a significant reduction of pathogenic microorganisms, the material needs to achieve high temperatures and the temperature must remain for various days, because microbial biomass is influenced directly by it.

The highest value of total coliforms was observed in $\mathrm{OC}_{4}$, which probably occurred due to the higher percentage of bovine manure used in the composition of the pile (Table 1), which favored the formation of the organic compost $\mathrm{OC}_{4}$. Additionally, only $\mathrm{OC}_{4}$ showed values of thermotolerant coliforms, but they are within the limits for Class I organic composts (CONAMA resolution proposal 02/2016).

The removal and/or reduction of pathogens in organic composts is extremely relevant, especially when the organic compost is intended for the production of vegetables, which in general are consumed fresh and need to be pure and healthy, free from pathogens that can lead to diseases. 
Therefore, the results ensure the stability of the produced composts, since there was a complete microbiological decomposition, free from pathogens and toxicity.

\section{Conclusions}

All the produced composts reached the maturation stage with satisfactory contents of humic substances, macronutrients and micronutrients, indicating that the food residues can be used as source of carbon in compost piles.

The concentrations of heavy metals in the organic composts were lower than those established in the main European and American legislations, as well as in the NI $n^{0} 27 / 2006$ of the Secretariat of Agriculture and Livestock Defense (SDA) and in the resolution proposal 02/2016 (CONAMA process 02000.001228/2015-37).

The composts suffered a complete microbial decomposition, which led to the reduction and/or removal of contaminant microbiological agents, showing absence of total coliforms, thermotolerant coliforms and Salmonella.

The composting of biodegradable residues does not have factors of risk to the public health, emerging as an initiative and means of recycling of food leftovers, avoiding negative environmental impacts.

\section{References}

Berton, R. S., Pires, A. M. M., Andrade, S. A. L., Abreu, C. A., Ambrosano, E. J., \& Silveira, A. P. D. (2006). Toxicidade do níquel em plantas de feijão e efeitos sobre a microbiota do solo. Pesq. Agrop. Bras., 41(8), 1305-1312. https://doi.org/10.1590/S0100-204X2006000800014

Bulcão, L. G., \& Albano, H. A. (2010). O gerenciamento de resíduos sólidos na Região Metropolitana II do Estado do Rio de Janeiro. Rev. de Gest. Soc. Ambi., 4(1), 75-85.

Cai, Y., Mo, C., Wu, Q., Zeng, Q., \& Katosoyiannis, A. (2007). Concentration and speciation of heavy metals in six different sewage sludge-composts. J. Hazard. Mater, 147(3), 1063-1072. https://doi.org/10.1016/ j.jhazmat.2007.01.142

Cavalcanti, C. R., Souza, F. C. S., \& Alves, G. S. (2011). Estudo do gerenciamento da coleta seletiva dos resíduos sólidos no município de Mossoró-RN. Holos., 4(1), 51-64.

CONAMA. (2010). Casa Civil, Subchefia Para Assuntos Jurídicos, Lei $n^{\circ} 12.305$, de 02 de agosto de 2010. Brasília: MMA. Retrieved June 11, 2016, from http://www.mma.gov.br/port/conama/legiabre.cfm? codlegi $=636$

CONAMA. (2016). Proposta de Resolução de 16/02/2016, processo no 02000.001228/2015-37. Brasília: MMA.

Ferreira, A. R., Camacho, R. G. V., \& Alcântara Neto, A. Q. (2012). Avaliação e diagnóstico ambiental dos resíduos sólidos gerados no município de Mossoró/RN. Rev. Geotemas., 2(1), 55-67.

Inácio, C. T., \& Miller, P. R. M. (2009). Compostagem: Ciência e prática aplicadas a gestão de resíduos (1st ed., p. 156). Rio de Janeiro: Embrapa Solos.

Liang, C., Das, K., \& McClendon, R. (2003). The influence of temperature and moisture contents regimes on the aerobic microbial activity of a biosolids composting blend. Biores. Technol., 86(2), 131-137. https://doi.org/10.1016/S0960-8524(02)00153-0

Malavolta, E. (1980). Elementos de nutrição mineral de plantas (1st ed., p. 251). São Paulo: Editora Agronômica Ceres.

Manios, T., \& Stetinford, E. (2006). Heavy metals fractionation during the thermophilic phase of sewage sludge composting in aerated static piles. J. Environ. Sci. Health., 41(7), 1235-1244. https://doi.org/10.1080/ 10934520600656513

Matiz, A., Martínez, M. M., Gutiérrez, V., Pardo, S., Ordúz, S., Moreno, R., \& Idárraga, G. (2015). Wastewater biosolids composting and their effect on Lactuca sativa L. Germination. Acta Hortic., 1076, 37-44 https://doi.org/10.17660/ActaHortic.2015.1076.3

Orrico Júnior, M. A. P., Orrico, A. C. A., \& Lucas Júnior, J. L. (2009). Compostagem da fração sólida da água residuária de suinocultura. Eng. Agrícola., 29(3), 483-491. https://doi.org/10.1590/S0100-6916200900 0300015

Pereira Neto, J. T. (2007). Manual de compostagem: Processo de baixo custo (p. 81). Viçosa: UFV. 
Pires, A. M. M., \& Andrade, C. (2006). Metais pesados em solos tratados com lodo de esgoto. In C. Sposito \& W. Ribeiro (Eds.), Gestão de resíduos na agricultura e agroindústria (p. 205-232). Botucatu: Fepaf.

Primo, D. C., Fadigas, S. F., Carvalho, J. C. R., Schmidt, C. D. S., \& Borges Filho, A. C. S. (2010). Avaliação da qualidade nutricional de composto orgânico produzido com resíduos de fumo. Rev. Bras. Eng. Agrí. Amb., 14(7), 742-746. https://doi.org/10.1590/S1415-43662010000700009

Secretaria de Defesa Agropecuária. (2006). Instrução normativa $N^{o} 27$ de 05/06/2006. Brasília: Diário Oficial da União. Retrieved October 15, 2016, from http://www.diariodasleis.com.br/busca/exibelink.php?numlink $=211215$

Silva, F. A. S., \& Azevedo, C. A. V. (2016). The Assistat Software Version 7.7 and its use in the analysis of experimental data. African J. Agric. Res., 11(39), 3733-3740. https://doi.org/10.5897/AJAR2016.11522

Silva, F. C. (2009). Manual de análises químicas de solo, plantas e fertilizantes (2nd ed., p. 627). Brasília: Embrapa Informação Tecnológica.

Siqueira, R. S. (1995). Manual de Microbiologia de alimentos (1st ed., p. 159). Brasília: Embrapa, SPI; Rio de Janeiro: Embrapa, CTAA.

Swift, R. S. (2001). Sequestration of carbon by soil. Soil Sci., 166(11), 858-871. https://doi.org/10.1097/ 00010694-200111000-00010

Tedesco, M. J., Gianelo, C., Bissani, C. A., Bohnen, H., \& Volkweiss, S. J. (1995). Análise de solo, plantas e outros materiais. Porto Alegre: UFRGS.

Wood, B. W., Reilly, C. C., \& Nyczepir, A. P. (2006). Field deficiency of nickel in trees: Symptoms and causes. Acta Hort., 721(1), 83-97. https://doi.org/10.17660/ActaHortic.2006.721.10

\section{Copyrights}

Copyright for this article is retained by the author(s), with first publication rights granted to the journal.

This is an open-access article distributed under the terms and conditions of the Creative Commons Attribution license (http://creativecommons.org/licenses/by/4.0/). 